\title{
Comparing reunified and residential care facility children's wellbeing in Ghana: The role of hope
}

\author{
Spencer L. James \\ Brigham Young University - Provo, spencer_james@byu.edu \\ Jini L. Roby \\ Brigham Young University - Provo
}

Follow this and additional works at: https://scholarsarchive.byu.edu/facpub

Part of the Other Social and Behavioral Sciences Commons

\section{Original Publication Citation}

Spencer L. James and Jini L. Roby. 2019. “Comparing Reunified and Residential Care Facility Children's Wellbeing in Ghana: The Role of Hope." Children and Youth Services Review 96:316-325.

\section{BYU ScholarsArchive Citation}

James, Spencer L. and Roby, Jini L., "Comparing reunified and residential care facility children's wellbeing in Ghana: The role of hope" (2018). Faculty Publications. 4143.

https://scholarsarchive.byu.edu/facpub/4143

This Peer-Reviewed Article is brought to you for free and open access by BYU ScholarsArchive. It has been accepted for inclusion in Faculty Publications by an authorized administrator of BYU ScholarsArchive. For more information, please contact ellen_amatangelo@byu.edu. 


\title{
Comparing reunified and residential care facility children's wellbeing in Ghana: The role of hope
}

\author{
Spencer L. James ${ }^{\mathrm{a}, *}$, Jini L. Roby ${ }^{\mathrm{b}}$ \\ ${ }^{a}$ School of Family Life, Brigham Young University, United States \\ ${ }^{\mathrm{b}}$ School of Social Work, Brigham Young University, United States
}

\section{A R T I C L E I N F O}

\section{Keywords:}

Child Wellbeing

Deinstitutionalization

Reunification and reintegration

Hope

Child status index

Ghana

\begin{abstract}
A B S T R A C T
The U.N. Convention on the Rights of the Child (UNCRC) stipulates children are entitled to "a family environment... of happiness, love and understanding". Recent work on deinstitutionalization of children from residential care has found important child wellbeing differences, particularly around hope. Using data from Ghana-a country that has initiated reintegration of children from residential care facilities, therefore providing a natural opportunity for comparative research-we used hope, whether the child has been reunified with family/caregivers or remained in the care facility, and a statistical interaction of the two, along with controls, to predict the Child Status Index, an internationally-established measure of child wellbeing. We found hope was associated with greater wellbeing for both groups; the influence of hope, however, was stronger among reunified children. We briefly articulate mechanisms explaining why this may be and suggest that psychological wellbeing, particularly hope, may function as a moderator to help provide children with an important means of negotiating their environments.
\end{abstract}

\section{Introduction}

The U.N. Convention on the Rights of the Child (UNCRC) holds that all children, regardless of nationality, race, sex, language, religion, disability, or any other status, have the right to "grow up in a family environment...of happiness, love and understanding" (UN General Assembly, 1989, p. 1). Despite this, recent estimates suggest that 2.7 million children worldwide live in residential care facilities (Petrowski, Cappa, \& Gross, 2017), with 126,000 in Western and Central Africa, where this study took place, at the rate of 51 children in residential care per 100,000 (ibid.). Residential care is often relied on by families and governments as a default system of care when parental care and alternative forms of family-based care such as kinship and foster care, are not readily available. In addition, the HIV pandemic and urbanization have impacted the traditional practice of reciprocity-based foster care (Roby, 2011), putting rural families at an unequal position to their relatives in urban centers, likely increasing the choice by some families to place children in institutions instead of in kinship care. Further, residential care is often viewed by many as a more reliable care option by families, especially as a means of providing education for children. Ruis-Casares, Steele, Bangura, and Oyat (2017) found, in a populationbased study in Liberia, that two thirds of the rural, half of the urban, and one quarter of Greater Monrovia populations believed that children are better cared for in orphanages than in a family $(p<.001)$. These attitudes were co-present with misunderstanding and lack of knowledge about the subtler risks of separation compared to the more obvious benefits offered by residential facilities.

Institution-based care has come under sharp criticism in recent decades, as established research has shown that children flourish best when living in a family environment-in terms of better physical, social, cognitive, and emotional outcomes than children in residential care facilities (Csáky, 2009; Zeanah, Smyke, Koga, \& Carlson, 2005). Even when such care is used as a last resort, current international practice norms urge that it should be a temporary solution, and reunification efforts should be applied expeditiously to reunify children in RCFs with family-based caregivers (United Nations, 2010). Responding to this call, governments and civil society organizations have renewed efforts to deinstitutionalize care facilities and to return children to their communities and families. Many in the international community have lauded this trend while a minority has urged a closer look at the impact of reunification on children's wellbeing.

The threshold question in the ongoing debate is this: does reunification with family or other caregivers in the community (rather than remaining in the institution) actually serve children's best interests? The answer, it turns out, is perhaps more complex than previously conceptualized.

\footnotetext{
*Corresponding author at: 2095 JFSB, School of Family Life, Provo, UT, United States.

E-mail address: spencer_james@byu.edu (S.L. James).
} 
Recent work, employing data from a sample of Ghanaian children $\backslash$ adolescents and sophisticated statistical methods, compared children who had spent time in a residential care facility but had been reunified with their families (or other permanent caregiver(s)) with those remaining in the RCFs (James et al., 2017). The study identified important differences in child wellbeing outcomes, with children in RCFs reporting higher levels of wellbeing overall on the Child Status Index (CSI), measuring health, food, shelter, education, protection, and emotional health and social behavior, compared to their reunified counterparts. However, reunified children reported greater levels of hope than children remaining in RCFs, both on the agency and pathway scales of the Children's Hope Scale. This is important because hope is a well-researched key psychological strength (Valle, Huebner, \& Suldo, 2006) that has been linked to a variety of positive outcomes (Barnum, Snyder, Rapoff, Mani, \& Thompson, 1998; Ciarrochi, Parker, Kashdan, Heaven, \& Barkus, 2015; Gilman, Dooley, \& Florell, 2006; Hellman, Munoz, Worley, Feeley, \& Gillert, 2017) and has even been shown to moderate how traumatic experiences influence subsequent wellbeing (Tobin, 2014; Valle et al., 2006).

These seemingly conflicting sets of findings suggested, on one hand, that greater emphasis must be placed on more carefully designed and implemented reintegration programs to ensure children's temporal and material wellbeing, when such resources are feasible. On the other hand, they suggested that despite lower CSI scores, reunified children were poised for a greater future psycho-social trajectory, possibly due to the effects of reunification with family and community, such as increased sense of identity and belonging, individual attention from caregivers, and the shedding of the stigma attached to institutional care. These sets of findings suggested a possible practice and policy conundrum: is it best to keep children in RCFs until social welfare systems are mature enough to provide for their temporal needs better, or should we invest in children's sense of hope and future trajectory even while knowing that their material needs may suffer?

\subsection{Research questions}

Utilizing a new conceptual lens, this paper undertakes an examination of the role of hope in child wellbeing (as measured by the Child Status Index; O'Donnell, Nyangara, Murphy, \& Nyberg, 2008) differences between RCF-residing and reunified children. We ask several simple and important research questions: what role do psychological traits, particularly hope, play in child wellbeing? Put differently, do we see the same differences in child wellbeing across children in RCFs vs. reunified children at all levels of hope or do the differences between RCF and reunified children shift as hope increases ${ }^{1}$ ?

\subsection{Conceptual and theoretical foundations: the UNCRC and Hope theory}

Underlying this study, our conceptual foundation is comprised first of the nearly universally accepted notion that children develop best in a family environment, and that they have a right to family-based care as enshrined in the United Nations' Convention on the Rights of the Child (UNCRC; UN General Assembly, 1989) with parents and governments as duty bearers. Under the UNCRC, children also have the right to safety, health, education, nutrition, and care for their survival and proper development (UN General Assembly, 1989 Art. 3, 6, 18, 23, 24). Extreme poverty, lack of access to resources such as education, health, social welfare and case management services can create conditions that ultimately result in families struggling to care for their children (Better Care Network \& UNICEF, 2015). Consequently, many children enter residential care facilities to meet their basic needs. At times, this system can become the 'default' for dealing with the millions of orphans and

\footnotetext{
${ }^{1}$ Of course, with cross-sectional data it is plausible that wellbeing predicts hope, a point we return to in both the results and discussion section.
}

vulnerable children (Meintjes, Moses, Berry, \& Mampane, 2007), despite the fact that nearly all of them $(80-90 \%$ by one estimate; Williamson \& Greenberg, 2010) have a family member with whom they could be reunited.

Governments and child rights organizations have consequently focused attention on reunifying children with their families. To date, however, much of the literature on reunification has focused on children who have spent time as child soldiers, living on the streets, or involved in the sex industry (Asquith \& Turner, 2008; Betancourt, Brennan, Rubin-Smith, Fitzmaurice, \& Gilman, 2010; Eleke, 2006; Harris, Johnson, Young, \& Edwards, 2011). One recent review (Wedge, 2013) noted that analytical (vs. descriptive) studies of reunification are extremely rare. To date, we are only aware of two academic studies (James et al., 2017; Nsabimana, 2016) that have focused on the impact of reunification efforts for children who have spent time in residential care facilities, despite Wedge's call for such studies that "could ultimately shed much light on the effectiveness of various approaches to family reintegration" (Wedge, 2013, p. 39). This article builds upon the findings of James et al. (2017), who found that while children remaining in RCFs enjoyed a higher level of 'tangible' benefits such as education, shelter, food, and health, the reintegrated children enjoyed a higher level of hope. In this article we ask, first, how is hope related to overall child wellbeing? And second, is the influence of hope different for reunified vs. RCF children?

Our other conceptual framework is Snyder's Hope Theory (Snyder et al., 1997). As a childhood psychological construct (Snyder et al., 1997), hope, Snyder argued, is an inherently future-oriented construct composed of three, interrelated principles: goals, agency and pathways (Snyder, 2000; Snyder et al., 1996). Goals, which can be short- or longterm, lie at the heart of the theory and vary according to the importance and likelihood of achievement one ascribes to them. Pathways refer to one's perceived ability to create paths toward achieving goals, with high hope individuals often thinking of multiple routes. This ability to create paths, and often multiple paths, can be particularly helpful when confronting obstacles. Agency refers to motivations and determinations that underlie and drive the action, ensuring the individual progresses toward the goal. Hope theory contends that reaching one's goals will lead to positive emotions while failure to do so may elicit negative ones and require individuals to engage in coping behaviors.

In terms of wellbeing, one could theorize that setting goals, envisioning pathways for reaching them, and possessing the determination to bring them about through persistent work may help alleviate the influence of structural barriers. That is, hope may be one mechanism by which children and adolescents can, in part, shape their world via future-oriented thinking and commitment to working toward that vision in the present.

\subsection{Measuring children's hope}

Couched in the movement toward positive psychology, the Children's Hope Scale (CHS), employed here, is a well-established, selfreport measure regarding children's orientation toward future goals (Hellman et al., 2017). Despite its status as relative newcomer among the study of psychological characteristics, several studies have studied hope in sub-Saharan Africa, ${ }^{2}$ especially South Africa. Interestingly, research from urban South Africa suggests it may be better to use the total hope score (i.e., combine the subscales) rather than employ the agency and pathway subscales separately due to factors that load across the two subscales (Guse, de Bruin, \& Kok, 2016). Further validating the hope scale for use on the African subcontinent, Savahl, Casas, and

\footnotetext{
${ }^{2}$ Because only one quantitative study has employed hope in Ghana (Wilson, 2015), we discuss research on hope in sub-Saharan Africa more generally as it is likely to be more culturally informative to the Ghanaian context than research focusing on the United States or other developed nations.
} 
Adams (2016) showed that the CHS showed good overall fit across socioeconomic groups. Even though some have tried to develop different hope scales specifically for the African sub-continent, the differences between the proposed scale and the original Snyder Hope scale appear minimal, especially in the context of stressful life experiences (Maree, Maree, \& Collins, 2008b). Furthermore, there is no evidence of gender differences in hope in a sample of South African youth (van der Westhuizen (née Coetzee), Beer, \& Bekwa, 2013) although there is preliminary evidence for race differences, with black college students reporting higher levels of hope than their white counterparts but, again, no gender differences (Maree et al., 2008b). Along with other studies (Maree, Maree, \& Collins, 2008a), these studies demonstrate that the CHS has been usefully employed in sub-Saharan Africa.

\subsection{Hope and child wellbeing}

Hope has been linked to children's outcomes across several domains (Barnum et al., 1998; Ciarrochi et al., 2015; Gilman et al., 2006). Children with high levels of hope may be better problem-solvers (Pedrotti, Edwards, \& Lopez, 2010), are more optimistic (Snyder et al., 1997), and are often better able to cope and adapt to new, often stressful, situations (Chang \& Desimone, 2001; Gilman et al., 2006; Hellman \& Gwinn, 2017; Lewis \& Kliewer, 1996; Valle, Huebner, \& Suldo, 2004). Hope has been conceptualized as a psychological strength that can serve as a buffer against negative influences (Valle et al., 2006), and has also been linked to improved academic performance (Marques, Lopez, \& Pais-Ribeiro, 2011; Worrell \& Hale, 2001), although this connection is inconsistent (Ayyash-Abdo, Sanchez-Ruiz, \& Barbari, 2016).

More directly on point for this study, hope has also been linked to dimensions of child wellbeing. In Ghana, hope has been qualitatively and quantitatively (for females) linked to life satisfaction (Wilson, 2015), with similar findings from South Africa, particularly among low SES adolescents (Raats, 2015). Hope has also been shown to alleviate the adverse effects of traumatic experiences among African refugees in Australia (Tobin, 2014). Beyond this, recent work has shown that hope mediates the association between average household age and household consumption, respectively, and sexual debut (Hill et al., 2017), as well as the relationship between time perspective and life satisfaction (Pallini, Milioni, Laghi, \& Vecchio, 2016). This may be because hope is an enduring characteristics that can facilitate connections between self, others, and external settings (Yohani \& Larsen, 2009) and is linked to wellbeing (Guse \& Vermaak, 2011), with moderately high bivariate correlations (in a sample of South African adolescents) with psychosocial well-being $(r=0.57)$, emotional wellbeing $(r=0.44)$, social wellbeing $(r=0.41)$, and psychological wellbeing $(r=0.58)$.

\section{Method}

\subsection{Sample}

Data for the analyses were collected between 2014 and 2016 in partnership with the motivating organizations, namely the non-governmental organization Kaeme (http://kaeme.org) and the government of Ghana's Department of Social Welfare. Lists of children who had been reunified for at least six months were provided by RCF directors, and access to children remaining in RCFs was provided at selected RCFs with the help of government officials. Our final sample consisted of 204 RCF children and 157 reunified children $(n=361)$.

The authors' Institutional Review Board approved all instruments and procedures. Further permission was provided by relevant Ghanaian governmental authorities. Consent for interviews, conducted in English or Twii depending on child's preference, were obtained from the government and the head of the RCF and/or children's parents/guardians. RCF and reunified children were interviewed within eyesight but out of hearing distance from their adult caregiver to ensure privacy to express genuine thoughts and feelings. The child's assent was obtained prior to the interview through verbal request to conduct the interview and then explaining their right to refuse to answer any question(s) or stop the interview at any time without repercussion. A trained team of government/Kaeme social workers and Ghanaian/American university students, under the supervision of a social work professor from the authors' university, interviewed children at a variety of residential care facilities in the Ashanti region. Other interviews were conducted over the next year by both Kaeme social workers and Ghanaian government officials with RCF children living in the Brong-Ahafo and Volta regions. $^{3}$

We used a similar process for reunified children interviews. We first obtained a governmental approval letter and then contacted directors ${ }^{4}$ of every RCF we could locate, requesting lists of reunified children who had returned at least six months prior. American and Ghanaian college students were then paired and trained, primarily by local team members, in interviewing techniques, culturally-sensitive practices, and survey methods. Each pair then interviewed a number of reunified children in the child's place of residence. A local social worker was hired to locate and interview reunified children over the next two years. Interviews were carried out in all regions of Ghana except the Upper East region. ${ }^{5}$ Participating children and their families were compensated with a basket of food stuffs, including rice and cooking oil.

\subsection{Measures}

We conceptualize child wellbeing as a multidimensional construct encompassing measures of children's social, emotional, and physical wellbeing. To do this, we employ the Child Status Index (O'Donnell et al., 2008; O'Donnell, Nyangara, Murphy, Cannon, \& Nyberg, 2013) which has gained international acceptance as a developmental indicator of child wellbeing and has high reliability and validity (O'Donnell et al., 2013). The Child Status Index provides a holistic and multidimensional perspective on children's rights that incorporates internationally-established benchmarks of child wellbeing. We employed the Child Status Index which combines multiple dimensions of wellbeing because an overreliance on one set of indicators may provide an incomplete picture of how well the child is faring.

\subsection{Dependent variables}

The Child Status Index (O'Donnell et al., 2013), consisting of twelve questions that address children's access to food and nutrition, shelter and care, legal and social protection from abuse and exploitation, psychosocial skills, and education, measures children's access to basic needs. Responses include good, fair, bad, or very bad and is coded so higher values indicate higher levels of child wellbeing.

\subsection{Independent variables}

Our primary independent variable was whether a child was currently in a residential care facility (RCF) at the time of interview or had

\footnotetext{
${ }^{3}$ All but a handful of RCF interviews were conducted jointly by American students and Ghanaian partners with government social workers available for consultation.

${ }^{4}$ In some instances, directors were very helpful, even escorting us on visits to the reunified children's homes. Other RCF directors proved less amiable. Some claimed they had no record of such children, others said they were too busy, and in some instances the director was unwilling to meet with project staff or even help us locate the RCF itself.

${ }^{5}$ None of the children identified lived in the Upper East region, although there are very likely some reunified children living there. About $20 \%$ of the reunified children were interviewed by American students and Ghanaian partners, with the remaining $80 \%$ interviewed by a compensated Ghanaian government social worker paid for his time, travel, and expertise.
} 
been reunified with her/his family or other community-based caregivers. We measured this with a dummy variable where 0 meant that a child had been reunified with family and 1 indicated a child was in the RCF when we spoke with them. In light of the critical importance of children's future orientation, we also employed the Children's Hope Scale (Snyder et al., 1996, 1997), which assesses respondent's hope pathways and hope agency, which together yield an overall level of hope. Hope pathways refer to the routes/strategies individuals use to achieve desired goals. Hope agency refers to the motivation/ confidence a person has to pursue the path leading to their desired goals. Responses vary from 1 none of the time to 6 all of the time. Research suggests using overall hope scale rather than using the subscales separately due to factors that cross-load across the subscales (Guse et al., 2016).

Control variables included respondent's age, gender, and whether the child was a single (one parent deceased) or double (both parents deceased) orphan or whether it was not explicitly mentioned in the interviews. Controls also included time spent in the orphanage (in months), whether the child had any mental or physical problems/limitations, the number of consumer goods (radio, television, telephone refrigerator, bicycle, motorcycle, car, or cellular phone) in the household, and the child's internalizing and externalizing scores from the Strength and Difficulties Questionnaire (A. Goodman, Lamping, \& Ploubidis, 2010; R. Goodman, 1997; Hoosen, Davids, de Vries, \& ShungKing, 2018) to account for behavioral issues.

\subsection{Analysis}

We employed linear regression models (see Eq. 1) to estimate the relationship between RCF vs. reunified children, hope, and child wellbeing as measured by the Child Status Index (CSI):

$C S I_{i}=R C F_{i}+$ Hope $_{i}+R C F * H_{o p e}+\chi_{i}+\varepsilon_{i}$

where an individual's ${ }_{i}$ ) score on the CSI is modeled as a function of whether an individual child was in the RCF or reunified, their hope score, and an interaction term between RCF and hope (created by multiplying the values together). Also included is a vector of covariates $\left(\chi_{i}\right)$ associated with child wellbeing and potential confounders in the relationship between child wellbeing and RCF/hope, and a residual term that encompasses all remaining error associated with variables not accounted for by or not correlated with variables in the model. We modeled hope as a non-linear, quadratic term because preliminary analyses suggested doing so improved model fit. We also tested a quadratic term for time spent in the RCF (one of our control variables) but found no evidence that justified doing so.

To deal with missing data, we employed multiple imputation. Despite relatively small amounts $(\sim 5 \%)$, missing data can influence the estimation procedures used to obtain coefficients and standard errors (Acock, 2005) by reducing sample size through listwise deletion; this raises the probability of making Type II errors. To combat this, we generated ten datasets of values representing the possible distribution of plausible values using Stata and the assumption of missing at random, a key assumption behind nearly all widely employed missing data algorithms. Consequently, our estimates are less biased and more efficient than they would have been with listwise deletion (Johnson \& Young, 2011). These datasets were then jointly analyzed with the standard errors adjusted for the variability introduced through the imputation process. Doing so also adjusts the coefficients and standard errors for possible bias due to missing data. We checked the data before and after imputation for irregularities that may have occurred during the imputation process; we found no meaningful variation in the means, standard deviations, or ranges.

\section{Results}

Table 1 presents descriptive statistics for the sample obtained from
Table 1

Descriptive statistics for independent variables, $N=361$.

\begin{tabular}{llll} 
& $\begin{array}{l}\text { Reunified } \\
(n=157)\end{array}$ & RCF $(n=204)$ & Total \\
& & & \\
\hline Child status index total (CSI) & 42.3 & 44.6 & 43.6 \\
Hope scale total & $(5.57)$ & $(3.19)$ & $(4.52)$ \\
& 14.0 & 9.96 & 11.7 \\
Female & $(7.40)$ & $(7.10)$ & $(7.49)$ \\
& 0.42 & 0.45 & 0.44 \\
Age & $(0.50)$ & $(0.50)$ & $(0.50)$ \\
& 15.7 & 13.2 & 14.3 \\
Double orphan & $(3.21)$ & $(2.79)$ & $(3.23)$ \\
Single orphan & 0.20 & 0.22 & 0.21 \\
& $(0.40)$ & $(0.42)$ & $(0.41)$ \\
Orphan status not mentioned & 0.34 & 0.40 & 0.37 \\
Years in RCF & $(0.47)$ & $(0.49)$ & $(0.48)$ \\
Known physical/mental & 0.46 & 0.38 & 0.42 \\
limitation & $(0.50)$ & $(0.49)$ & $(0.49)$ \\
\# Consumer goods in residence & 5.17 & 5.98 & 5.63 \\
& $(3.32)$ & $(3.48)$ & $(3.43)$ \\
Externalizing problems & 0.24 & 0.20 & 0.22 \\
Internalizing problems & $(0.43)$ & $(0.40)$ & $(0.41)$ \\
& $(1.60)$ & 2.73 & 2.76 \\
& 3.52 & $(1.79)$ & $(1.71)$ \\
& $(2.99)$ & 3.47 & 3.49 \\
& 5.92 & $(2.57)$ & $(2.76)$ \\
& $(3.64)$ & 5.23 & 5.53 \\
& & $(3.40)$ & $(3.52)$ \\
\hline
\end{tabular}

Standard deviations in parentheses.

the 361 children and adolescents in Ghana. As expected, reunified children reported scored lower on the Child Status Index than their RCF counterparts but higher on the hope scale. RCF children were a little younger (15.7 vs. 13.2) than reunified children and slightly more likely to be both double and single orphans. RCF children reported spending nearly a full year (5.98 vs. 5.17$)$ more in a care facility than the reunified children, although $24 \%$ of reunified children had some known physical/mental limitation compared to just $20 \%$ of RCF children. Additionally, reunified children reported (5.92 vs. 5.23) more internalizing problems than their RCF counterparts.

Table 2 presents the results of the linear regression analysis. In the first column, we present the results excluding the interaction term, which is shown in the second column. On average, children living in the RCF reported CSI levels 2.88 points higher than reunified children, even after controlling for the other variables. In terms of hope, each one-unit increase in hope was associated with a 0.54 increase in the child status index. Because hope ranged from 0 to 30 , this means we would expect that a child who scored 10 points higher on the hope scale is predicted to report a child status index score that is 5.4 points higher $(0.54 * 10)$, after accounting for all other variables in the model. Model fit was adequate, with an adjusted R2 of 0.42 , meaning we accounted for $42 \%$ of the variance (i.e., possible reasons for variation) in the Child Status Index.

We next included an interaction term (see Eq. 1), which tests whether the positive influence of hope on the Child Status Index differs for RCF and reunified children. The second column of Table 2 shows that the interaction term was statistically significant, suggesting that the positive influence of hope on the CSI did indeed work differently for RCF vs. reunified children. To aid interpretation, we present these results graphically in Fig. 1. The results suggested that, although the overall influence of hope is positive for both groups, the influence of hope on the CSI was significantly stronger for reunified children $(\mathrm{b}=0.39, p<.001)$ than RCF $(\mathrm{b}=0.20, \mathrm{p}<.001)$. Further post-hoc analyses (not shown due to space limitation but available upon request) revealed that at low and even modest levels of hope (between 0 and 21 on the x-axis of Fig. 1), RCF children reported significantly higher CSI scores (i.e., the difference between the two lines is significant). However, from 22 to 30 on the Hope Scale, there were no statistically 
Table 2

The influence of hope on the child status index for reunified and RCF children in Ghana.

\begin{tabular}{|c|c|c|}
\hline & $\begin{array}{l}\text { Child status index- } \\
\text { main effects }\end{array}$ & $\begin{array}{l}\text { Child status index- } \\
\text { interaction effects }\end{array}$ \\
\hline Total hope score & $\begin{array}{l}0.54^{* * *} \\
(0.11)\end{array}$ & $\begin{array}{l}0.69^{* * * *} \\
(0.12)\end{array}$ \\
\hline $\begin{array}{l}\text { Total hope score * total hope } \\
\quad \text { score }\end{array}$ & $\begin{array}{l}-0.01^{* * *} \\
(0.00)\end{array}$ & $\begin{array}{l}-0.01^{\text {**** }} \\
(0.00)\end{array}$ \\
\hline RCF & $\begin{array}{l}2.88^{\text {**** }} \\
(0.42)\end{array}$ & $\begin{array}{l}5.21^{* * * *} \\
(0.79)\end{array}$ \\
\hline Single orphan & $\begin{array}{l}-0.94 \\
(0.56)\end{array}$ & $\begin{array}{l}-0.69 \\
(0.57)\end{array}$ \\
\hline Not mentioned & $\begin{array}{l}-0.48 \\
(0.56)\end{array}$ & $\begin{array}{l}-0.41 \\
(0.56)\end{array}$ \\
\hline Age & $\begin{array}{l}-0.12 \\
(0.07)\end{array}$ & $\begin{array}{l}-0.12 \\
(0.07)\end{array}$ \\
\hline Years in RCF & $\begin{array}{l}0.02 \\
(0.06)\end{array}$ & $\begin{array}{l}0.02 \\
(0.06)\end{array}$ \\
\hline Female & $\begin{array}{l}0.87 \\
(0.39)\end{array}$ & $\begin{array}{l}0.90^{*} \\
(0.38)\end{array}$ \\
\hline Some limits/disabilities & $\begin{array}{l}0.52 \\
(0.47)\end{array}$ & $\begin{array}{l}0.37 \\
(0.46)\end{array}$ \\
\hline $\begin{array}{l}\text { \# Consumer goods in } \\
\text { residence }\end{array}$ & $\begin{array}{l}0.31^{*} \\
(0.12)\end{array}$ & $\begin{array}{l}0.34^{* *} \\
(0.12)\end{array}$ \\
\hline Externalizing problems & $\begin{array}{l}-0.17^{*} \\
(0.09)\end{array}$ & $\begin{array}{l}-0.22^{* *} \\
(0.09)\end{array}$ \\
\hline Internalizing problems & $\begin{array}{l}-0.34^{* * * *} \\
(0.07)\end{array}$ & 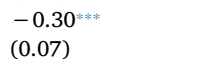 \\
\hline $\mathrm{RCF} *$ total hope score & & $\begin{array}{l}-0.19^{\text {**** }} \\
(0.06)\end{array}$ \\
\hline Constant & $\begin{array}{l}41.02^{* * * *} \\
(1.38)\end{array}$ & $\begin{array}{l}39.21^{* * * *} \\
(1.46)\end{array}$ \\
\hline R-Square & 0.44 & 0.46 \\
\hline Adj. R-Square & 0.42 & 0.44 \\
\hline
\end{tabular}

Reference Categories: RCF (Reunified); Single Orphan/Not Mentioned (Double Orphan); Female (Male).

$$
\begin{aligned}
& { }^{*} \mathrm{p}<.05 \\
& { }^{* *} \mathrm{p}<.01 \\
& { }^{* * *} \mathrm{p}<.001 .
\end{aligned}
$$

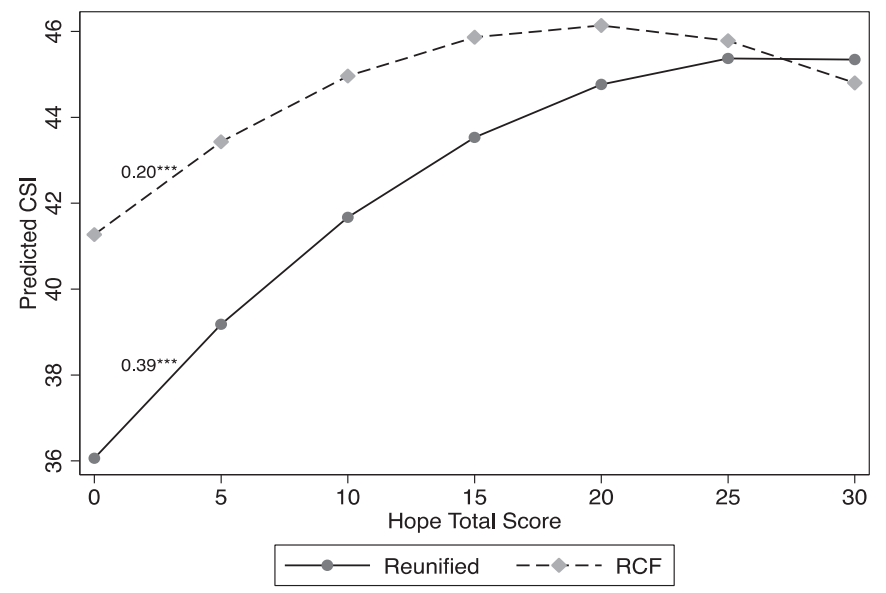

Fig. 1. The influence of hope on the child status index for reunified and institutionalized children in Ghana.

significant differences on the Child Status Index (only 12\% of our sample scored 22 or higher on hope). Thus, the previously observed differences in CSI between RCF and reunified children persist at lower and moderate levels of hope but disappear entirely at higher levels of hope. Model fit was again adequate; the adjusted R2 significantly improved slightly to 0.44 , meaning the interaction term accounts for an additional $2 \%$ of the variance by itself, over and above the independent influences of hope and experiencing reunification/remaining in the $\mathrm{RCF}$, along with all the other variables in the model.
Table 3

\begin{tabular}{|c|c|c|c|c|}
\hline & $\begin{array}{l}\text { Education \& } \\
\text { skills }\end{array}$ & $\begin{array}{l}\text { Education \& } \\
\text { skills }\end{array}$ & $\begin{array}{l}\text { Food \& } \\
\text { nutrition }\end{array}$ & $\begin{array}{l}\text { Food \& } \\
\text { nutrition }\end{array}$ \\
\hline Total hope score & $\begin{array}{l}0.091^{* *} \\
(0.032)\end{array}$ & $\begin{array}{l}0.122^{* * * *} \\
(0.033)\end{array}$ & $\begin{array}{l}0.066 \\
(0.031)\end{array}$ & $\begin{array}{l}0.086^{* * *} \\
(0.033)\end{array}$ \\
\hline $\begin{array}{l}\text { Total hope score * } \\
\text { total hope score }\end{array}$ & $\begin{array}{l}-0.002 \\
(0.001)\end{array}$ & $\begin{array}{l}-0.002 \\
(0.001)\end{array}$ & $\begin{array}{l}-0.001 \\
(0.001)\end{array}$ & $\begin{array}{l}-0.002 \\
(0.001)\end{array}$ \\
\hline $\mathrm{RCF}$ & $\begin{array}{l}0.533^{* * * *} \\
(0.115)\end{array}$ & $\begin{array}{l}1.084^{* * * *} \\
(0.212)\end{array}$ & $\begin{array}{l}0.570^{* * *} \\
(0.112)\end{array}$ & $\begin{array}{l}0.912^{* * * *} \\
(0.210)\end{array}$ \\
\hline Single orphan & $\begin{array}{l}-0.148 \\
(0.157)\end{array}$ & $\begin{array}{l}-0.090 \\
(0.154)\end{array}$ & $\begin{array}{l}-0.118 \\
(0.146)\end{array}$ & $\begin{array}{l}-0.082 \\
(0.147)\end{array}$ \\
\hline Not mentioned & $\begin{array}{l}-0.101 \\
(0.155)\end{array}$ & $\begin{array}{l}-0.083 \\
(0.152)\end{array}$ & $\begin{array}{l}-0.144 \\
(0.142)\end{array}$ & $\begin{array}{l}-0.133 \\
(0.143)\end{array}$ \\
\hline Age & $\begin{array}{l}-0.013 \\
(0.020)\end{array}$ & $\begin{array}{l}-0.013 \\
(0.020)\end{array}$ & $\begin{array}{l}0.003 \\
(0.018)\end{array}$ & $\begin{array}{l}0.004 \\
(0.018)\end{array}$ \\
\hline Years in RCF & $\begin{array}{l}-0.005 \\
(0.018)\end{array}$ & $\begin{array}{l}-0.006 \\
(0.018)\end{array}$ & $\begin{array}{l}0.004 \\
(0.018)\end{array}$ & $\begin{array}{l}0.004 \\
(0.018)\end{array}$ \\
\hline Female & $\begin{array}{l}0.034 \\
(0.107)\end{array}$ & $\begin{array}{l}0.039 \\
(0.105)\end{array}$ & $\begin{array}{l}0.116 \\
(0.107)\end{array}$ & $\begin{array}{l}0.118 \\
(0.107)\end{array}$ \\
\hline $\begin{array}{l}\text { Some limits/ } \\
\text { disabilities }\end{array}$ & $\begin{array}{l}-0.016 \\
(0.131)\end{array}$ & $\begin{array}{l}-0.049 \\
(0.130)\end{array}$ & $\begin{array}{l}0.143 \\
(0.128)\end{array}$ & $\begin{array}{l}0.122 \\
(0.128)\end{array}$ \\
\hline $\begin{array}{l}\text { \# Consumer goods } \\
\text { in residence }\end{array}$ & $\begin{array}{l}0.077^{*} \\
(0.033)\end{array}$ & $\begin{array}{l}0.085^{* * *} \\
(0.033)\end{array}$ & $\begin{array}{l}0.078 \\
(0.033)\end{array}$ & $\begin{array}{l}0.083^{*} \\
(0.033)\end{array}$ \\
\hline $\begin{array}{l}\text { Externalizing } \\
\text { problems }\end{array}$ & $\begin{array}{l}-0.068^{* *} \\
(0.023)\end{array}$ & $\begin{array}{l}-0.080^{* * * *} \\
(0.023)\end{array}$ & $\begin{array}{l}-0.010 \\
(0.023)\end{array}$ & $\begin{array}{l}-0.018 \\
(0.023)\end{array}$ \\
\hline $\begin{array}{l}\text { Internalizing } \\
\text { problems }\end{array}$ & $\begin{array}{l}-0.038^{*} \\
(0.018)\end{array}$ & $\begin{array}{l}-0.031 \\
(0.018)\end{array}$ & $\begin{array}{l}-0.063^{* * *} \\
(0.018)\end{array}$ & $\begin{array}{l}-0.059^{* * *} \\
(0.018)\end{array}$ \\
\hline $\begin{array}{l}\text { RCF * total hope } \\
\text { score }\end{array}$ & & $\begin{array}{l}-0.046^{* *} \\
(0.015)\end{array}$ & & $\begin{array}{l}-0.029 \\
(0.015)\end{array}$ \\
\hline Constant & $\begin{array}{l}6.804^{\text {****** }} \\
(0.392)\end{array}$ & $\begin{array}{l}6.402^{* * * *} \\
(0.411)\end{array}$ & $\begin{array}{l}6.585^{* * * *} \\
(0.368)\end{array}$ & $\begin{array}{l}6.336^{* * * *} \\
(0.388)\end{array}$ \\
\hline R-square & 0.260 & 0.281 & 0.206 & 0.215 \\
\hline Adj. R-square & 0.233 & 0.252 & 0.177 & 0.183 \\
\hline
\end{tabular}

the influence of hope on education/skills and food/nutrition between RCF and reunified children.

Reference Categories: RCF (Reunified); Single Orphan/Not Mentioned (Double Orphan); Female (Male).

$$
\begin{aligned}
& { }^{*} \mathrm{p}<.05 . \\
& { }^{* *} \mathrm{p}<.01 . \\
& \text { *** }^{*} \mathrm{p}<.001 .
\end{aligned}
$$

\subsection{Sensitivity analyses}

We next sought to explore this finding further. One concern could be how psychological mechanisms play into the previously observed associations. Specifically, we wondered if the observed correlation between hope and the Child Status Index was due to a correlation between hope and the 'psychosocial' dimension of the CSI, as both are psychological constructs. That is, we wondered if psychological mechanisms were driving the process. If, we speculated, the primary reason why hope and the CSI are linked is because both are psychological constructs, then any previously observed associations should be stronger for the psychosocial dimension on the CSI than for the other five dimensions. To test this, we examined each dimension of the CSI separately and examined the relationships observed in Table 2 for each one dimension.

Tables 3, 4, and 5 show our findings. These relationships are also displayed graphically in Fig. 2 to aid interpretation. The results confirmed that while hope remained positively and significantly linked to each of the six dimensions, there was no evidence that the relationship was stronger for the psychosocial dimension. In fact, the link between hope and the psychosocial dimension was on the weaker side among the various dimensions. We next examined whether the observed interaction, where hope had a more positive impact on CSI among reunified than RCF children, was more positive for the psychosocial dimension. Again, the results indicated that the link between hope and global child wellbeing on the overall CSI was not due to a strong influence of the CSI's 'psychosocial' dimension. In fact, the interaction term between RCF/reunified and hope was only significant for three of 
Table 4

The influence of hope on health and protection and food and nutrition between RCF and reunified children.

\begin{tabular}{|c|c|c|c|c|}
\hline & Health & Health & Protection & Protection \\
\hline Total hope score & $\begin{array}{l}0.094^{* * * *} \\
(0.028)\end{array}$ & $\begin{array}{l}0.112^{\text {f*** }} \\
(0.029)\end{array}$ & $\begin{array}{l}0.115^{\text {**** }} \\
(0.034)\end{array}$ & $\begin{array}{l}0.126^{* * *} \\
(0.036)\end{array}$ \\
\hline $\begin{array}{l}\text { Total hope score * total hope } \\
\text { score }\end{array}$ & $\begin{array}{l}-0.003^{\text {** }} \\
(0.001)\end{array}$ & $\begin{array}{l}-0.003^{* *} \\
(0.001)\end{array}$ & $\begin{array}{l}-0.002 \\
(0.001)\end{array}$ & $\begin{array}{l}-0.002 \\
(0.001)\end{array}$ \\
\hline $\mathrm{RCF}$ & $\begin{array}{l}0.574^{* * * *} \\
(0.098)\end{array}$ & $\begin{array}{l}0.901^{\text {***** }} \\
(0.185)\end{array}$ & $\begin{array}{l}0.282 \\
(0.121)\end{array}$ & $\begin{array}{l}0.476^{*} \\
(0.229)\end{array}$ \\
\hline Single orphan & $\begin{array}{l}-0.151 \\
(0.131)\end{array}$ & $\begin{array}{l}-0.117 \\
(0.133)\end{array}$ & $\begin{array}{l}-0.250 \\
(0.154)\end{array}$ & $\begin{array}{l}-0.229 \\
(0.156)\end{array}$ \\
\hline Not mentioned & $\begin{array}{l}0.001 \\
(0.128)\end{array}$ & $\begin{array}{l}0.012 \\
(0.127)\end{array}$ & $\begin{array}{l}-0.091 \\
(0.154)\end{array}$ & $\begin{array}{l}-0.085 \\
(0.155)\end{array}$ \\
\hline Age & $\begin{array}{c}-0.006 \\
(0.016)\end{array}$ & $\begin{array}{l}-0.005 \\
(0.016)\end{array}$ & $\begin{array}{l}-0.070^{\text {**** }} \\
(0.020)\end{array}$ & $\begin{array}{l}-0.070^{\text {**** }} \\
(0.020)\end{array}$ \\
\hline Years in RCF & $\begin{array}{l}-0.002 \\
(0.016)\end{array}$ & $\begin{array}{l}-0.003 \\
(0.016)\end{array}$ & $\begin{array}{l}0.010 \\
(0.019)\end{array}$ & $\begin{array}{l}0.010 \\
(0.019)\end{array}$ \\
\hline Female & $\begin{array}{l}0.173 \\
(0.093)\end{array}$ & $\begin{array}{l}0.176 \\
(0.092)\end{array}$ & $\begin{array}{l}0.193 \\
(0.115)\end{array}$ & $\begin{array}{l}0.194 \\
(0.115)\end{array}$ \\
\hline Some limits/disabilities & $\begin{array}{l}0.047 \\
(0.114)\end{array}$ & $\begin{array}{l}0.027 \\
(0.113)\end{array}$ & $\begin{array}{l}-0.036 \\
(0.140)\end{array}$ & $\begin{array}{c}-0.048 \\
(0.141)\end{array}$ \\
\hline \# Consumer goods in residence & $\begin{array}{l}0.019 \\
(0.030)\end{array}$ & $\begin{array}{l}0.024 \\
(0.030)\end{array}$ & $\begin{array}{l}0.061 \\
(0.035)\end{array}$ & $\begin{array}{l}0.064 \\
(0.035)\end{array}$ \\
\hline Externalizing problems & $\begin{array}{l}-0.032 \\
(0.020)\end{array}$ & $\begin{array}{l}-0.040 \\
(0.020)\end{array}$ & $\begin{array}{l}-0.041 \\
(0.025)\end{array}$ & $\begin{array}{l}-0.045 \\
(0.025)\end{array}$ \\
\hline Internalizing problems & $\begin{array}{l}-0.029 \\
(0.016)\end{array}$ & $\begin{array}{l}-0.025 \\
(0.016)\end{array}$ & $\begin{array}{l}-0.044^{*} \\
(0.020)\end{array}$ & $\begin{array}{l}-0.042 \\
(0.020)\end{array}$ \\
\hline RCF * total hope score & & $\begin{array}{l}-0.027^{*} \\
(0.013)\end{array}$ & & $\begin{array}{l}-0.016 \\
(0.016)\end{array}$ \\
\hline Constant & $\begin{array}{l}6.859^{\text {k非* }} \\
(0.324)\end{array}$ & $\begin{array}{l}6.620^{\text {*k* }} \\
(0.344)\end{array}$ & $\begin{array}{l}7.319^{* * *} \\
(0.397)\end{array}$ & $\begin{array}{l}7.178^{\text {**** }} \\
(0.421)\end{array}$ \\
\hline R-Square & 0.193 & 0.204 & 0.248 & 0.251 \\
\hline Adj. R-Square & 0.163 & 0.172 & 0.221 & 0.221 \\
\hline
\end{tabular}

Reference categories: RCF (Reunified); single orphan/Not mentioned (Double orphan); female (Male).

$$
\begin{aligned}
& { }^{*} \mathrm{p}<.05 . \\
& { }_{* *} \mathrm{p}<.01 . \\
& { }_{* *} \mathrm{p}<.001 .
\end{aligned}
$$

the six sub-scales including education \& skills, health, and shelter \& care. Importantly, it was not significant for the psychosocial dimension.

These sensitivity analyses confirm that the association between hope and child wellbeing as operationalized by the Child Status Index is not driven solely by the interrelationships between the psychological variables involved, namely hope and psychosocial wellbeing. In fact, the opposite is true-hope serves as a buffer, a particularly important one when predicting child wellbeing. Reunified children with high hope levels do not appear to experience the same differences in child wellbeing as reunified children with lower levels of hope. This is particularly true for education, health, and shelter/care.

An additional consideration is a natural consequence of our crosssectional data-we use hope to predict the Child Status Index but perhaps the reverse is true: children with higher levels of wellbeing on the CSI may have higher levels of hope. Of course, bidirectionality is a fact of life in the social sciences and wellbeing almost certainly influences hope (i.e., the CSI predicts the Children Hope Scale). We reasoned that if wellbeing predicts hope more than hope predicts wellbeing (that is, we should use hope as the dependent variable) then our finding that hope is more salient for reunified children may be because wellbeing predicts hope. Consequently, we might expect that among reunified children with lower wellbeing (i.e., low CSI), only those with moderate CSI feel hopeful. ${ }^{6}$ We examined scatterplots (Fig. 1) of the relationship between the CSI and hope scores, broken down by low (bottom third), moderate (middle third), and high (upper third) CSI, as well as the overall scatterplot across the complete range of CSI. As can be seen by the plot, while there are some outliers with low levels of hope and very

\footnotetext{
${ }^{6}$ We thank an anonymous reviewer for this suggestion.
}

Table 5

\begin{tabular}{|c|c|c|c|c|}
\hline & Psychosocial & Psychosocial & $\begin{array}{l}\text { Shelter \& } \\
\text { Care }\end{array}$ & Shelter \& Care \\
\hline Total hope score & $\begin{array}{l}0.079 * \\
(0.031)\end{array}$ & $\begin{array}{l}0.090^{* *} \\
(0.033)\end{array}$ & $\begin{array}{l}0.129 * * * \\
(0.035)\end{array}$ & $\begin{array}{l}0.168^{* * * *} \\
(0.036)\end{array}$ \\
\hline $\begin{array}{l}\text { Total hope score * } \\
\text { total hope score }\end{array}$ & $\begin{array}{l}-0.001 \\
(0.001)\end{array}$ & $\begin{array}{l}-0.001 \\
(0.001)\end{array}$ & $\begin{array}{l}-0.003^{*} \\
(0.001)\end{array}$ & $\begin{array}{l}-0.003^{* *} \\
(0.001)\end{array}$ \\
\hline $\mathrm{RCF}$ & $\begin{array}{l}0.409^{* * *} \\
(0.111)\end{array}$ & $\begin{array}{l}0.606^{* *} \\
(0.208)\end{array}$ & $\begin{array}{l}0.563^{* * * *} \\
(0.123)\end{array}$ & $\begin{array}{l}1.253^{* * *} \\
(0.228)\end{array}$ \\
\hline Single orphan & $\begin{array}{l}-0.293 \\
(0.163)\end{array}$ & $\begin{array}{l}-0.272 \\
(0.165)\end{array}$ & $\begin{array}{l}0.046 \\
(0.159)\end{array}$ & $\begin{array}{l}0.119 \\
(0.159)\end{array}$ \\
\hline Not mentioned & $\begin{array}{l}-0.180 \\
(0.151)\end{array}$ & $\begin{array}{l}-0.174 \\
(0.151)\end{array}$ & $\begin{array}{l}0.093 \\
(0.161)\end{array}$ & $\begin{array}{l}0.116 \\
(0.160)\end{array}$ \\
\hline Age & $\begin{array}{l}-0.013 \\
(0.019)\end{array}$ & $\begin{array}{l}-0.013 \\
(0.019)\end{array}$ & $\begin{array}{l}-0.025 \\
(0.020)\end{array}$ & $\begin{array}{l}-0.024 \\
(0.020)\end{array}$ \\
\hline Years in RCF & $\begin{array}{l}0.005 \\
(0.017)\end{array}$ & $\begin{array}{l}0.005 \\
(0.017)\end{array}$ & $\begin{array}{l}0.003 \\
(0.018)\end{array}$ & $\begin{array}{l}0.002 \\
(0.018)\end{array}$ \\
\hline Female & $\begin{array}{l}0.109 \\
(0.103)\end{array}$ & $\begin{array}{l}0.111 \\
(0.103)\end{array}$ & $\begin{array}{l}0.313^{* *} \\
(0.116)\end{array}$ & $\begin{array}{l}0.319 * * \\
(0.114)\end{array}$ \\
\hline $\begin{array}{l}\text { Some limits/ } \\
\text { disabilities }\end{array}$ & $\begin{array}{l}0.104 \\
(0.126)\end{array}$ & $\begin{array}{l}0.093 \\
(0.127)\end{array}$ & $\begin{array}{l}0.214 \\
(0.141)\end{array}$ & $\begin{array}{l}0.173 \\
(0.139)\end{array}$ \\
\hline $\begin{array}{l}\text { \# Consumer goods } \\
\text { in residence }\end{array}$ & $\begin{array}{l}0.022 \\
(0.032)\end{array}$ & $\begin{array}{l}0.025 \\
(0.032)\end{array}$ & $\begin{array}{l}0.053 \\
(0.036)\end{array}$ & $\begin{array}{l}0.064 \\
(0.035)\end{array}$ \\
\hline $\begin{array}{l}\text { Externalizing } \\
\text { problems }\end{array}$ & $\begin{array}{l}0.017 \\
(0.022)\end{array}$ & $\begin{array}{l}0.012 \\
(0.023)\end{array}$ & $\begin{array}{l}-0.034 \\
(0.025)\end{array}$ & $\begin{array}{l}-0.049 \\
(0.025)\end{array}$ \\
\hline $\begin{array}{l}\text { Internalizing } \\
\text { problems }\end{array}$ & $\begin{array}{l}-0.104^{* * * *} \\
(0.018)\end{array}$ & $\begin{array}{l}-0.101^{* * * *} \\
(0.018)\end{array}$ & $\begin{array}{l}-0.056^{* * *} \\
(0.020)\end{array}$ & $\begin{array}{l}-0.046^{*} \\
(0.020)\end{array}$ \\
\hline $\begin{array}{l}\text { RCF * total hope } \\
\text { score }\end{array}$ & & $\begin{array}{l}-0.016 \\
(0.015)\end{array}$ & & $\begin{array}{l}-0.058^{* * *} \\
(0.016)\end{array}$ \\
\hline Constant & $\begin{array}{l}6.945^{* * * *} \\
(0.373)\end{array}$ & $\begin{array}{l}6.801^{\text {**** }} \\
(0.393)\end{array}$ & $\begin{array}{l}6.225^{* * * *} \\
(0.396)\end{array}$ & $\begin{array}{l}5.721^{* * * *} \\
(0.416)\end{array}$ \\
\hline R-square & 0.270 & 0.273 & 0.251 & 0.279 \\
\hline Adj. R-square & 0.243 & 0.244 & 0.223 & 0.250 \\
\hline
\end{tabular}

The influence of hope on psychosocial needs and shelter/care between RCF and reunified children.

Reference categories: RCF (reunified); single orphan/not mentioned (double orphan); female (male).

$$
\begin{aligned}
& { }^{*} \mathrm{p}<.05 . \\
& { }^{* *} \mathrm{p}<.01 . \\
& { }^{* * *} \mathrm{p}<.001 .
\end{aligned}
$$

low CSI in the 'Low CSI' graph, the bulk of low-hope children (say, 0-5 on the Total Hope Score) have moderate levels of wellbeing, as measured by the CSI. The results, then, provided little evidence that, among reunified children in the bottom third of the CSI distribution, only those with moderate levels of CSI are hopeful (upper-leftmost scatterplot in Fig. 1), thereby supporting our use of CSI as the dependent variable.

We further explored the issue by examining the Pearson correlation coefficient between the CSI and hope at each level of CSI (available upon request) to see if this relationship differed across levels. The results suggested a positive, significant correlation across all three levels, each $\sim 0.25$. Together, there is little evidence that the influence of wellbeing on hope is stronger than the influence of hope on wellbeing (Fig. 3).

\section{Discussion}

This paper sheds light on a key debate in global child welfare practice as greater evidence emerges on the importance of family-based care for child wellbeing and subsequent reunification efforts. Because residential care facilities have too often become the default solution for difficult family situations (Meintjes et al., 2007), reunification efforts have become increasingly important in bringing practice into compliance with the principles set out in the UNCRC to ensure that all children have access to environments optimized for their development and care. Recent evidence from Ghana (James et al., 2017) suggested something of a conundrum: while reunified children reported higher levels of hope, children in RCFs reported greater levels of wellbeing on the Child Status Index. Consequently, we undertook to see if, in line 

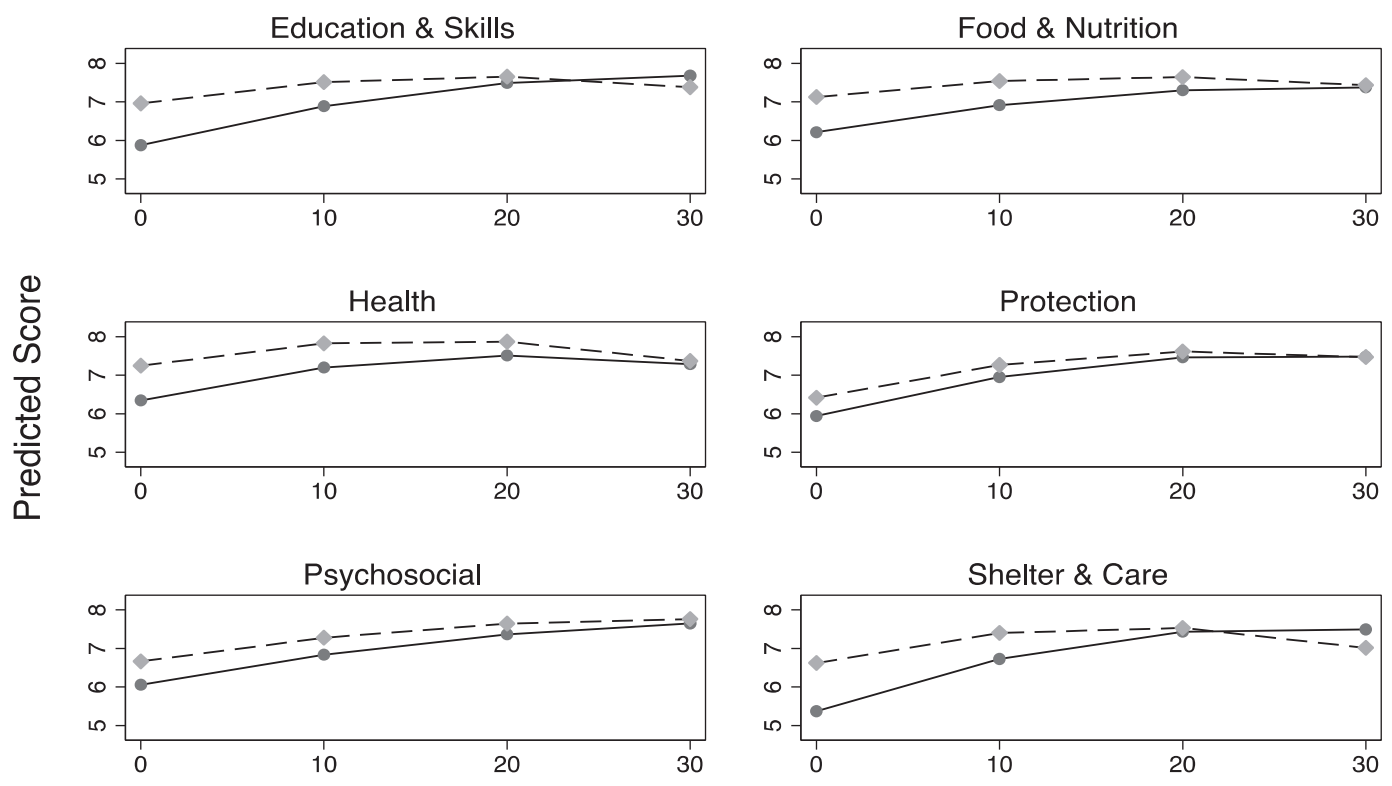

Hope Total Score

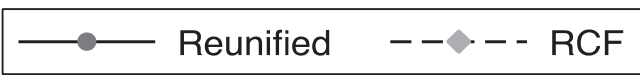

Fig. 2. The differential impact of hope on components of the child status index in Ghana.
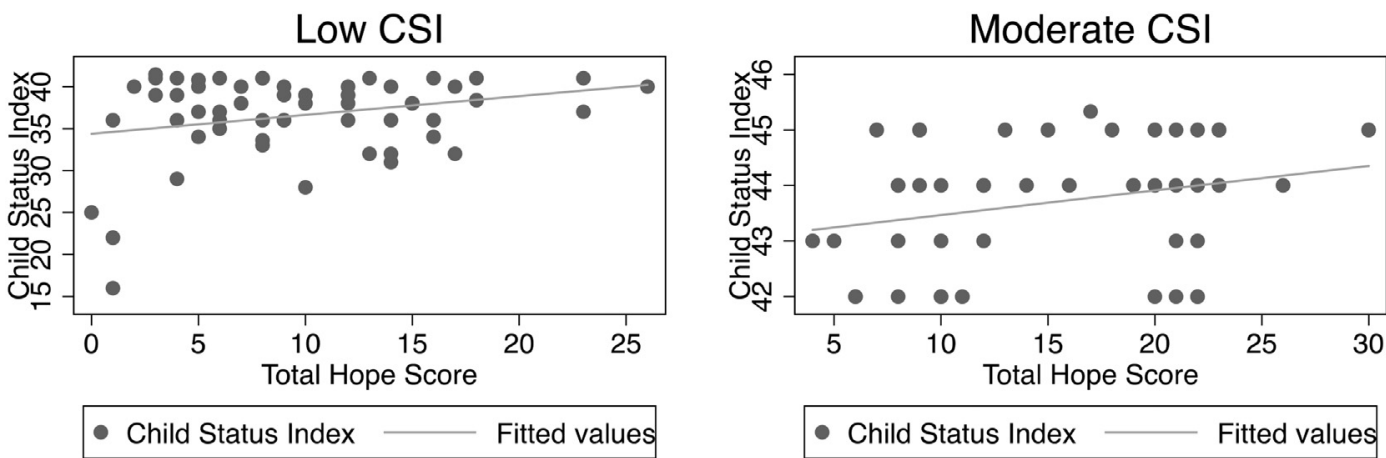

High CSI
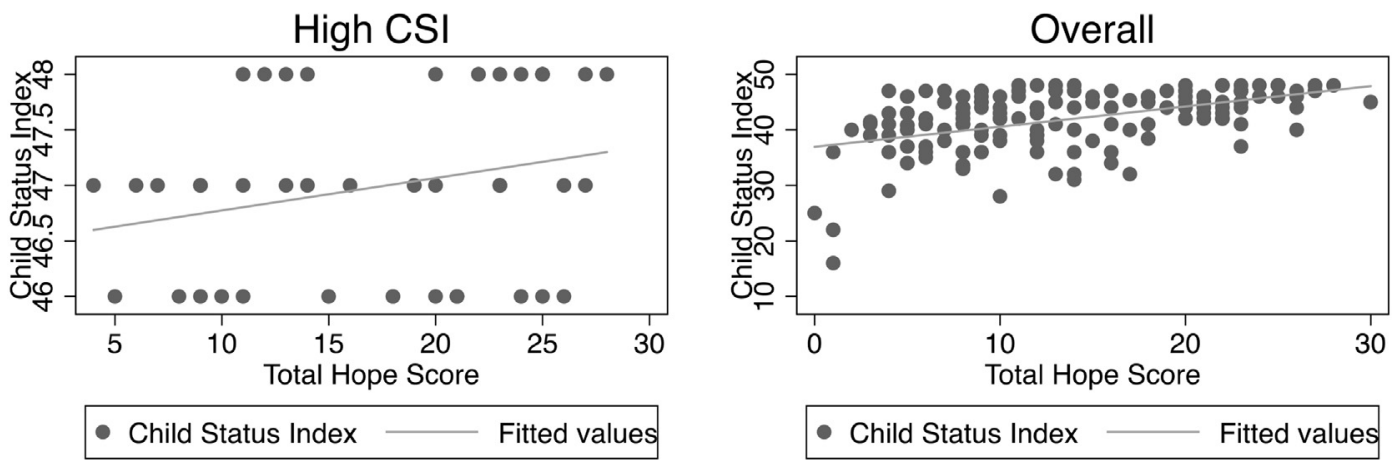

Fig. 3. The relationship between hope and CSI among reunified children.

with prior literature (Snyder, 2000; Snyder et al., 1997; Valle et al., 2006) on the African subcontinent (Maree et al., 2008a, 2008b), hope could moderate the relationship between experiencing reunification and wellbeing on the CSI.

The results suggested that the positive link between hope and child wellbeing was stronger for reunified children and could partially help shed light on why reunified children scored lower overall on the CSI than their RCF counterparts. At lower levels of hope, we see persistent differences in CSI, with children in RCFs scoring better. At higher levels of hope, however, these differences disappear-hopeful children, whether reunified or in the care facility, have similar and comparatively high levels of wellbeing. This finding, that children near the uppermost decile of hope exhibit markedly different patterns, is not without precedent in the literature, as Marques, Lopez, Fontaine, Coimbra, and Mitchell (2015) found that children in the top $10 \%$ of hope had greater psychological and academic scores than children with 
average or low hope.

This is an important finding, as it suggests that hope may represent an additional mechanism for improving child wellbeing both in the RCF setting and post-reunification. For children being reunified, the reality for the majority is that their access to tangible necessities lowers when they return to their impoverished families without support. However, because hope is a strong force, it may magnify the potential for achieving wellbeing outcomes, when accompanied by reunification support such as access to appropriate resources and follow-up monitoring services. It is also possible that the ending of a stressful life event itself, such as an exit from residential care via a reunification process, produces an increase in hope. Because hope is tied to so many positive outcomes (Otis, Huebner, \& Hills, 2016), the reunification process itself may be seen as a positive psychosocial intervention, although further study would be required before drawing a firm conclusion. For children remaining in RCFs, there may be a complex set of interactions between children's hope levels and the control, albeit limited, they can exercise in their environme3nt. For example, children with hope may be more proactive in asking for, or securing, more food, additional tutoring, or accessing health care when needed. Their hopeful attitudes may garner more attention from and interaction with staff who may tend to be warmer and more protective toward these children. Their goal-orientation may keep them focused more on their education, health, and other tangible goods. Either way, promoting a higher level of hope while children live in care facilities may contribute to a better quality of life there and smoother transition to the aging out process.

The question then becomes one of how to increase hope in vulnerable children who are placed in institutions, whether they age out or reunify before reaching adulthood. The role of prevention cannot be overemphasized, both in the form of promoting secure attachments and strengthening parental capacity. A long and established literature on positive psychology suggests that hope is developed and maintained through children's parental and other early familial relationships; acute, stressful life events can produce or impede the cognitive, emotional, and motivational processes that give rise to hope (Blake \& Norton, 2014). Consequently, the home environment, where many of these relationships and stressful life events have their roots, constitutes one of the most powerful socializing agents for children's hope development (Snyder, 2000). This is primarily because a child's secure attachment, or lack thereof, influences these processes. The lack of secure attachments and other adverse childhood experiences (ACEs) may impede positive hope development and may even have the potential to stifle future hope (Snyder, 2000), especially if major life stressors are present. Among the most trauma-inducing childhood experiences, being abused, neglected, living with substance abusing parents, witnessing domestic violence, and being separated from parents through imprisonment have been found to produce lifelong negative consequences including mental disorders (Anda et al., 2006).

Because most of, if not all the, children in our sample have already experienced significant stressful life events, multiple ACEs, poor attachments, and broken family relationships, any attempts to improve hope must start with preventing entrance into care in the first place through family strengthening programs and the provision of adequate resources to impoverished families. Key to this process will be avoiding initial separation from caregivers where possible and facilitating smoother transitions into family-based care otherwise. Among capacity building activities for parents, they may benefit from training to be 'hope coaches' (Shorey, Snyder, Rand, \& Hockemeyer, 2002) that empower children to set goals and then help them plan ways and maintain motivations along the way to achieving them. Hopeful caregivers may also 'coach' children by exhibiting positive attitudes and behaviors while the child experiences the ups and downs of life themselves (Shorey et al., 2002). Children then begin to cultivate internal, cognitive working models of how the world works and how they work in and through the world to plan for the future (Otis et al., 2016).

Unfortunately, however, caring for children in RCFs will continue for the foreseeable future, and it is necessary to discuss how children can be best served while in that setting. As a priority, reintegration should be a primary goal for each child who enters the RCF, and this process should be conducted with careful assessment, planning, case management and follow up services for at least one year post-reunification. In addition, regardless of how imminent the reunification may be, RCFs should facilitate visits to and from family and friends, where appropriate. For this reason, children who must reside in a RCF should be kept close to their families throughout their stay, and efforts should be made to fund transportation for visits. Of course, there may be extreme cases in which visits are not recommended to safeguard the welfare of the child and for children without family to visit. In such cases, responsible authorities may locate volunteers to fill that role, and continue to search for an alternative family-based care.

While this effort is taking place, hope can be promoted for children through several evidence-supported methods. Of critical importance is to ensure low staff-to-children ratio so that each child has the opportunity to form meaningful attachment to staff who can offer stable and enduring relationships with the children. This can be facilitated by both staff training and structural changes in the institution. In a large study in Russia, McCall et al. (2013) conducted a study where caregivers were trained in one set of 'baby homes' to engage in more warm, sensitive, responsive, and child-directed interactions with the caregiver, coupled with structural changes to create smaller, more home-like caregiving units for the children. The second set of institutions only made structural changes, and the third group made no changes. The changes, as measured by the Home Observation for Measurement of the Environment (HOME) Inventory, showed that children's physical, cognitive, and social-emotional development improved substantially in the double intervention homes. The study also emphasized the importance of maintaining the changes over long term, in their case for four years, to produce sustainable change. The use of short and medium term volunteers should be avoided, to minimize the repeated experience of disrupted attachments (Smith Rotabi, Roby, \& Bunkers, 2016). Staff discontinuance should be handled with sensitivity to manage the personal loss to children.

For older children, it is important to focus on the child's ability to set and achieve goals while in the RCF. Through individualized treatment plans each child should be assisted in articulating a set of achievable goals and supported in realizing those goals. In a German study $(n=448)$ with children (aged 6-18) in institutions who had experienced critical life events, researchers found that those who achieved individual and social goals experienced significant improvements in mental health and fewer behavior problems (Kleinrahm, Keller, Lutz, Kölch, \& Fegert, 2013). Goal setting should also be a part of the reintegration process, to prepare for the transition and to begin to address some of the challenges they are likely to face.

Fostering prosocial competitions may also aid in the development and enhancement of hope. Developmentally appropriate youth sports can increase the sense of competence, confidence and cooperation (Fraser-Thomas, Côté, \& Deakin, 2005). Contrarily, it can also be a cause for a child to feel less competent depending on their athletic prowess and how the competition is handled. It is best to encourage and facilitate the development of a wide array of activities to highlight individual talents and abilities of both boys and girls of all ages.

It will also be important to provide mentoring relationships both within and outside of the RCF, particularly as youth near the transition period to aging out of the RCF. There is very little research evidence on the effect of mentoring for youth in RCFs, but a randomized controlled trial in the U.S. with youth in public foster care showed that children and youth who participated in a 9-month mentoring and skills program reported fewer mental problems and reported better quality of life compared to the control group (Taussig \& Culhane, 2010). In qualitative interviews, Zambian youth who had recently left RCF-based care reported the lack of role models and mentoring to be among the harshest realities of aging out (unpublished manuscript). Many youth 
confided that in the absence of a mentor/role model, it is easy to fall into a life style that may include substance abuse and crimes.

Worth noting, of course, is the possibility that hope is a function of wellbeing, a topic we've touched on several times. Literature suggests that hope is, in part, the product of stable family relationships, something these children have not had (Blake \& Norton, 2014). Further, hope may be diminished when children undergo traumatic experiences (e.g., adverse childhood experiences), something these children have in abundance. In the social sciences, effects often go in both directions and we acknowledge the likelihood of a reciprocal effect between hope and wellbeing. However, given cross-sectional data, we opted to employ wellbeing as the dependent variable and predicted it with hope. This is because literature has shown that hope predicts wellbeing (Jiang, Huebner, \& Hills, 2014; Jovanović, 2013; Marques, Lopez, Fontaine, Coimbra, \& Mitchell, 2014; Wong \& Lim, 2009), including longitudinal studies (Valle et al., 2006). Worth noting as well is that fact that if the primary direction of the relationship is incorrect (i.e., wellbeing$>$ hope rather than hope- $>$ wellbeing), then it is very unclear why the influence of hope would be stronger among reunified children, who have lower levels of wellbeing. If wellbeing lead to notable increases in hope, then we would a priori expect to find higher levels of hope among the RCF children instead. It therefore seems plausible, based on our results and also existing literature, to, at least in this instance, employ the CSI (wellbeing) as the dependent variable.

We note, however, that we are not advocating for abandoning provision of economic, financial, social, educational, and health-related resources. Structural barriers should remain the primary focus for helping Africa's poorest children, including the provision of resources to cover basic needs across all dimensions of wellbeing. However, we are saying that hope may help alleviate the influence of structural barriers by enabling children to perceive pathways around these barriers and sustain the motivation necessary to accomplish those plans via setting goals and being future-oriented. Of course, it would be nonsensical to blame a child for not being hopeful. Hope, as previously mentioned, is partly a product of stable family relationships, home environments, and supportive personal relationships. It should come as no surprise that children who have spent time in Ghanaian RCFs might struggle to be hopeful. Rather, hope should be seen as a possible mechanism for helping children negotiate the very real barriers in their lives while policymakers and child advocates work to reduce the structural effect of those barriers.

Like any paper, this one has limitations. First, perhaps the most obvious, is the sample. Although we tried diligently to include a wide range of children from both RCF and reunified contexts, this is a convenience sample, so it remains unclear about the extent to which these findings generalize, as Ghana is a unique case and no sampling frame of the population of reunified and RCF children was available or even existed. Second, we do not know whether the differences we observe here persist through time, although we did ensure that reunified children had spent at least six months in their new homes before we interviewed them to avoid a 'honeymoon' effect. Future research, particularly longitudinal studies that employ representative samples drawn from the population using probability methods, would be very useful. This study, however, constitutes a solid first step toward answering the questions addressed here. A third limitation is a natural outgrowth of the second, namely that we have cross-sectional data and can make no claims to causality, merely associations. Despite suggestive evidence that hope predicts wellbeing, both empirical and conceptual, bidirectionality is possible, even likely; wellbeing likely influences hope. Thus, we make no claims about the causality of our observed relationships although further work is merited.

In short, this article contributes to the global push for mental health and psychological wellbeing as key components of overall wellbeing, particularly as it relates to worldwide reunification efforts. Greater focus on psychological wellbeing, particularly hope, may help provide children with important means of improving their environments. When combined with carefully designed national caregiving and social welfare schemes, these results underline the importance of supporting children's physical and psychosocial developmental needs both while during and after spending time in residential care facilities. They also underscore the necessity of well-conceived and supportive family-based care. We join with prior research (James et al., 2017) in calling for greater efforts to attend to reunified children's needs, particularly psychosocial ones such as hope, because they may, at least in some instances, help close the gap in their wellbeing. These needs can best be met when countries and child welfare agencies focus on national schemes with trained personnel for improved recordkeeping and sustained case management as well as carefully designed, implemented, and funded national programs.

\section{Competing interests statement}

We, Spencer L. James and Jini L. Roby, have no competing interests in the outcomes, data, or other findings of this manuscript.

\section{References}

Acock, A. C. (2005). Working with Missing Values. Journal of Marriage and Family, 67(November), 1012-1028. https://doi.org/10.1111/j.1741-3737.2005.00191.x.

Anda, R. F., Felitti, V. J., Bremner, J. D., Walker, J. D., Whitfield, C., Perry, B. D., ... Giles, W. H. (2006). The enduring effects of abuse and related adverse experiences in childhood: A convergence of evidence from neurobiology and epidemiology. European Archives of Psychiatry and Clinical Neuroscience, 256(3), 174-186. https:// doi.org/10.1007/s00406-005-0624-4.

Asquith, S., \& Turner, E. (2008). Recovery and reintegration of children from the effects of sexual exploitation and related trafficking. Geneva: Switzerland. Retrieved from https://www.childwatch.uio.no/research/migration-children/trafficking/Recovery_ and Reintegration English.pdf.

Ayyash-Abdo, H., Sanchez-Ruiz, M. J., \& Barbari, M. L. (2016). Resiliency predicts academic performance of Lebanese adolescents over demographic variables and hope. Learning and Individual Differences, 48, 9-16. https://doi.org/10.1016/j.lindif.2016. 04.005.

Barnum, D. D., Snyder, C. R., Rapoff, M. A., Mani, M. M., \& Thompson, R. (1998). Hope and social support in psychological adjustment of children who have survived burn injuries and their matched controls. Children's Health Care, 27(1), 15-30. https://doi. org/10.1207/s15326888chc2701.

Betancourt, T. S., Brennan, R. T., Rubin-Smith, J., Fitzmaurice, G. M., \& Gilman, S. E. (2010). Sierra Leone's Former Child soldiers: A Longitudinal Study of risk, protective Factors, and Mental Health. Journal of the American Academy of Child and Adolescent Psychiatry. 49(6), 606-615. https://doi.org/10.1016/j.jaac.2010.03.008.

Better Care Network, \& UNICEF (2015). Country care profile-Ghana. Retrieved from http://www.bettercarenetwork.org/sites/default/files/Country.Care.Profile-Ghana_ 0.pdf.

Blake, J., \& Norton, C. (2014). Examining the relationship between hope and attachment: A meta-analysis. Psychology, 5(6), 556-565. https://doi.org/10.4236/psych.2014. 56065.

Chang, E. C., \& Desimone, S. L. (2001). The influence of hope on appraisals, coping, and dysphoria: A test of hope theory. Journal of Social and Clinical Psychology, 20(2), 117-129. https://doi.org/10.1521/jscp.20.2.117.22262.

Ciarrochi, J., Parker, P., Kashdan, T. B., Heaven, P. C. L., \& Barkus, E. (2015). Hope and emotional well-being: A six-year study to distinguish antecedents, correlates, and consequences. Journal of Positive Psychology, 10(6), 520-532. https://doi.org/10. $1080 / 17439760.2015 .1015154$.

Csáky, C. (2009). Keeping children out of harmful institutions: Why we should be investing in family-based care. London, UK: Save the Children. Retrieved from https://www. savethechildren.org.uk/sites/default/files/docs/Keeping_Children_Out_of_Harmful_ Institutions_Final_20.11.09_1.pdf.

Eleke, I. D. M. (2006). Effective reintegration of female child soldiers: Reality or rhetoric? Case study of Northern Uganda. Universidade Eduardo Mondlane Mozambique. Retrieved from http://repository.up.ac.za/handle/2263/1221.

Fraser-Thomas, J. L., Côté, J., \& Deakin, J. (2005). Youth sport programs: An avenue to foster positive youth development. Physical Education \& Sport Pedagogy, 10(1), 19-40. https://doi.org/10.1080/1740898042000334890.

General Assembly, U. N. (1989). Convention on the Rights of a Child. United Nations, Treaty Series, 1577(November), 1-15. https://doi.org/10.2307/4065371.

Gilman, R., Dooley, J., \& Florell, D. (2006). Relative levels of hope and their relationship with academic and psychological indicators among adolescents. Journal of Social and Clinical Psychology, 25(2), 166-178. https://doi.org/10.1521/jscp.2006.25.2.166.

Goodman, A., Lamping, D. L., \& Ploubidis, G. B. (2010). When to use broader internalising and externalising subscales instead of the hypothesised five subscales on the strengths and difficulties questionnaire (SDQ): Data from british parents, teachers and children. Journal of Abnormal Child Psychology, 38(8), 1179-1191. https://doi. org/10.1007/s10802-010-9434-x.

Goodman, R. (1997). The strengths and difficulties questionnaire: A research note. Journal of Child Psychology, 38(5), 581-586. https://doi.org/10.1111/j.1469-7610. 
1997.tb01545.x.

Guse, T., de Bruin, G. P., \& Kok, M. (2016). Validation of the Children's Hope Scale in a Sample of South African Adolescents. Child Indicators Research, 9(3), 757-770. https://doi.org/10.1007/s12187-015-9345-z.

Guse, T., \& Vermaak, Y. (2011). Hope, psychosociai well-being and socioeconomic status among a group of South African adolescents. Journal of Psychology in Africa, 21(4), 527-534. https://doi.org/10.1080/14330237.2011.10820493.

Harris, M. S., Johnson, K., Young, L., \& Edwards, J. (2011). Community reinsertion success of street children programs in Brazil and Peru. Children and Youth Services Review, 33(5), 723-731. https://doi.org/10.1016/j.childyouth.2010.11.017.

Hellman, C. M., \& Gwinn, C. (2017). Camp HOPE as an intervention for children exposed to domestic violence: A program evaluation of hope, and strength of character. Child and Adolescent Social Work Journal, 34(3), 269-276. https://doi.org/10.1007/ s10560-016-0460-6.

Hellman, C. M., Munoz, R. T., Worley, J. A., Feeley, J. A., \& Gillert, J. E. (2017). A reliability generalization on the children's hope scale. Child Indicators Research. https://doi.org/10.1007/s12187-017-9467-6.

Hill, L. M., Abler, L., Maman, S., Twine, R., Kahn, K., MacPhail, C., \& Pettifor, A. (2017). Hope, the household environment, and sexual risk behaviors among young women in rural South Africa. AIDS and Behavior, 1-11. https://doi.org/10.1007/s10461-0171945-9 Hptn 068

Hoosen, N., Davids, E. L., de Vries, P. J., \& Shung-King, M. (2018). The strengths and difficulties questionnaire (SDQ) in Africa: A scoping review of its application and validation. Child and Adolescent Psychiatry and Mental Health, 12(1), 1-39. https:// doi.org/10.1186/s13034-017-0212-1.

James, S. L., Roby, J. L., Powell, L. J., Teuscher, B. A., Hamstead, K. L., \& Shafer, K. (2017). Does family reunification from residential care facilities serve children's best interest? A propensity-score matching approach in Ghana. Children and Youth Services Review, 83(May), 232-241. https://doi.org/10.1016/j.childyouth.2017.10.032.

Jiang, X., Huebner, E. S., \& Hills, K. J. (2014). Parent attachment and early adolescents' life satisfaction: The mediating effect of hope. Psychology in the Schools, 50(4), 340-352. https://doi.org/10.1002/pits.

Johnson, D. R., \& Young, R. (2011). Toward best practices in analyzing datasets with missing data: Comparisons and recommendations. Journal of Marriage and Family, 73(5), 926-945. https://doi.org/10.1111/j.1741-3737.2011.00861.x.

Jovanović, V. (2013). Evaluation of the children's hope scale in Serbian adolescents: Dimensionality, measurement invariance across gender, convergent and incremental validity. Child Indicators Research, 6(4), 797-811. https://doi.org/10.1007/s12187013-9195-5.

Kleinrahm, R., Keller, F., Lutz, K., Kölch, M., \& Fegert, J. M. (2013). Assessing change in the behavior of children and adolescents in youth welfare institutions using goal attainment scaling. Child and Adolescent Psychiatry and Mental Health, 7(1), 1-11. https://doi.org/10.1186/1753-2000-7-33.

Lewis, H., \& Kliewer, W. (1996). Hope, coping, and adjustment among children with sickle cell disease: Tests of mediator and moderator models. Journal of Pediatric Psychology, 21(1), 25-41. Retrieved from http://ezproxy.lib.utexas.edu/login?url= http://search.ebscohost.com/login.aspx? direct $=$ true $\& \mathrm{db}=$ psyhref\&AN $=$ JPP.BA. BE.LEWIS.HCAACW.

Maree, D. J. F., Maree, M., \& Collins, C. (2008a). Constructing a South African hope measure. Journal of Psychology in Africa, 18(1), 167-177. https://doi.org/10.1080/ 14330237.2008.10820183.

Maree, D. J. F., Maree, M., \& Collins, C. (2008b). The relationship between hope and goal achievement. Journal of Psychology in Africa. https://doi.org/10.1080/14330237. 2008.10820172.

Marques, S. C., Lopez, S. J., Fontaine, A. M., Coimbra, S., \& Mitchell, J. (2014). Validation of a Portuguese version of the Snyder hope scale in a sample of high school students. Journal of Psychoeducational Assessment, (8), 32. https://doi.org/10.1177/ 0734282914540865.

Marques, S. C., Lopez, S. J., Fontaine, A. M., Coimbra, S., \& Mitchell, J. (2015). How much hope is enough? Levels of hope and students' psychological and school functioning. Psychology in the Schools, 52(4), https://doi.org/10.1002/pits. 21833.

Marques, S. C., Lopez, S. J., \& Pais-Ribeiro, J. L. (2011). "Building hope for the future": A program to foster strengths in middle-school students. Journal of Happiness Studies, 12(1), 139-152. https://doi.org/10.1007/s10902-009-9180-3.

McCall, R. B., Groark, C. J., Fish, L., Muhamedrahimov, R. J., Palmov, O. I., \& Nikiforova, N. V. (2013). Maintaining a social-emotional intervention and its benefits for institutionalized children. Child Development, 84(5), 1734-1749. https://doi.org/10. $1111 /$ cdev.12098.

Meintjes, H., Moses, S., Berry, L., \& Mampane, R. (2007). Home truths : The phenomenon of residential care for children in a time of AIDS, Cape Town, South Africa.

Nsabimana, E. (2016). The process of institutionalization-deinstitutionalization and children's psychologicla adjustment in Rwanda: Parents matter. University of Fribourg.

O'Donnell, K., Nyangara, F., Murphy, R., Cannon, M., \& Nyberg, B. (2013). Child status index: A tool for monitoring the wellbeing of children orphaned or otherwise made vulnerable as a result of HIV/AIDS. Chapel Hill, North Carolina.

O'Donnell, K., Nyangara, F., Murphy, R., \& Nyberg, B. (2008). Child status index.

Otis, K. L., Huebner, E. S., \& Hills, K. J. (2016). Origins of early adolescents' hope:
Personality, parental attachment, and stressful life events. Canadian Journal of School Psychology, 31(2), 102-121. https://doi.org/10.1177/0829573515626715.

Pallini, S., Milioni, M., Laghi, F., \& Vecchio, G. M. (2016). The ant and the grasshopper: Adolescents' time perspective, satisfaction with life and the mediating role of hope. Journal of Happiness Studies, 1-14. https://doi.org/10.1007/s10902-016-9821-2.

Pedrotti, J. T., Edwards, L. M., \& Lopez, S. J. (2010). Promoting hope: Suggestions for school counselors. Professional School Counseling, 12(2), 100-107. https://doi.org/10. 5330/PSC.n.2010-12.100.

Petrowski, N., Cappa, C., \& Gross, P. (2017). Estimating the number of children in formal alternative care: Challenges and results. Child Abuse and Neglect, 70, 388-398. https://doi.org/10.1016/j.chiabu.2016.11.026.

Raats, C. (2015). Investigating the relationship between hope and life satisfaction among children in low and middle income communities in Cape Town. University of the Western Cape.

Roby, J. L. (2011). Children in informal alternative care. (New York).

Ruis-Casares, M., Steele, R., Bangura, R., \& Oyat, G. (2017). Preventing parent-child separation: myths and facts from a KAP survey in central and western Liberia. Global Social Welfare, 4, 219-231. https://doi.org/10.1007/s40609-017-0090-8 Preventing.

Savahl, S., Casas, F., \& Adams, S. (2016). Validation of the children's hope scale amongst a sample of adolescents in the Western Cape region of South Africa. Child Indicators Research, 9(3), 701-713. https://doi.org/10.1007/s12187-015-9334-2.

Shorey, H. S., Snyder, C. R., Rand, K. L., \& Hockemeyer, J. R. (2002). Somewhere over the rainbow: Hope theory weathers its first decade. Psychological Inquiry, 13(4), 322-331. https://doi.org/10.1207/S15327965PLI1304.

Smith Rotabi, K., Roby, J. L., \& Bunkers, K. M. (2016). Altruistic exploitation: Orphan tourism and global social work. British Journal of Social Work, (November 2015), 1-18. https://doi.org/10.1093/bjsw/bcv147.

Snyder, C. R. (2000). The past and possible futures of hope. Journal of Social and Clinical Psychology, 19(1), 11-28. https://doi.org/10.1521/jscp.2000.19.1.11.

Snyder, C. R., Hoza, B., Pelham, W. E., Rapoff, M., Ware, L., Danovsky, M., ... Stahl, K. J. (1997). The development and validation of the children's hope scale. Journal of Pediatric Psychology, 22(3), 399-421. https://doi.org/10.1093/jpepsy/22.3.399.

Snyder, C. R., Sympson, S. C., Ybasco, F. C., Borders, T. F., Babyak, M. A., \& Higgins, R. L (1996). Development and validation of the State Hope Scale. Journal of Personality and Social Psychology, 70(2), 321-335. https://doi.org/10.1037/0022-3514.70.2 321.

Taussig, H. N., \& Culhane, S. E. (2010). Impact of a mentoring and skills group program on mental health outcomes for maltreated children in foster care. Archives of Pediatrics and Adolescent Medicine, 164(8), 739-746. https://doi.org/10.1001/ archpediatrics.2010.124.

Tobin, S. (2014). Hope within trauma for refugee women: Whispers and echoes through shadows and reflections. The University of Sydney. Retrieved from http://ses.library. usyd.edu.au:80/handle/2123/12786.

United Nations (2010). Guidelines for the alternative care of children.

van der Westhuizen (née Coetzee), S., Beer (2013). The Role of Gender and Race in Sense of Coherence and Hope Orientation Results. In M. Wissing (Ed.). Well-Being Research in South AfricaNetherlands: Dordrecht: Springer. https://doi.org/10.1007/978-94007-6368-5_22 (pp. 479-500).

Valle, M. F., Huebner, E. S., \& Suldo, S. M. (2004). Further evaluation of the children's hope scale. Journal of Psychoeducational Assessment, 22(4), 320-337. https://doi.org/ $10.1177 / 073428290402200403$.

Valle, M. F., Huebner, E. S., \& Suldo, S. M. (2006). An analysis of hope as a psychological strength. Journal of School Psychology, 44(5), 393-406. https://doi.org/10.1016/j.jsp. 2006.03 .005 .

Wedge, J. (2013). Reaching for Home: Global learning on family reintegration in low and lower-middle income countries. Retrieved from http://www.bettercarenetwork.org/ sites/default/files/attachments/Reaching.for.Home-Globaly.Learning.on.Family. Reintegration.pdf.

Williamson, J., \& Greenberg, A. (2010). Families, not orphanages (No. 1). Better care network working paper series. New York, NY. Retrieved from http://www.crin.org/docs/ Families.Not.Orphanages.pdf\%5Cnhttp://symposium.jointcouncil.org/wp-content/ uploads/2012/04/Williamson-Families-Not-Orphanages-for-JCICS.pdf.

Wilson, A. (2015). An exploration of aspects of mental health in school-going adolescents in Ghana. Stellenbosch University.

Wong, S. S., \& Lim, T. (2009). Hope versus optimism in Singaporean adolescents: Contributions to depression and life satisfaction. Personality and Individual Differences, 46(5-6), 648-652. https://doi.org/10.1016/j.paid.2009.01.009.

Worrell, F. C., \& Hale, R. L. (2001). The relationship of hope in the future and perceived school climate to school completion. School Psychology Quarterly, 16(4), 370-388. https://doi.org/10.1521/scpq.16.4.370.19896.

Yohani, S. C., \& Larsen, D. J. (2009). Hope lives in the heart: Refugee and immigrant children's perceptions of hope and hope-engendering sources during early years of adjustment. Canadian Journal of Counselling, 43(4), 246-264.

Zeanah, C. H., Smyke, A. T., Koga, S. F., \& Carlson, E. (2005). Attachment in institutionalized and community children in Romania. Child Development, 76(5), 1015-1028. https://doi.org/10.1111/j.1467-8624.2005.00894.x. 